\title{
Oxidative Addition of Aryl Electrophiles to a Prototypical Nickel(0) Complex: Mechanism and Structure/Reactivity Relationships
}

\author{
Sonia Bajo, ${ }^{\dagger, \S}$ Gillian Laidlaw, ${ }^{\dagger}$ Alan R. Kennedy, ${ }^{\dagger}$ Stephen Sproules, ${ }^{*}{ }^{\ddagger}{ }^{\ddagger}$ and David J. Nelson ${ }^{*}, \dagger \odot$ \\ ${ }^{\dagger}$ WestCHEM Department of Pure and Applied Chemistry, University of Strathclyde, Thomas Graham Building, 295 Cathedral Street, \\ Glasgow G1 1XL, U.K. \\ ${ }^{*}$ WestCHEM School of Chemistry, University of Glasgow, University Place, Glasgow G12 8QQ U.K.
}

Supporting Information

ABSTRACT: Detailed kinetic studies of the reaction of a model $\mathrm{Ni}^{0}$ complex with a range of aryl electrophiles have been conducted. The reactions proceed via a fast ligand exchange preequilibrium, followed by oxidative addition to produce either $\left[\mathrm{Ni}{ }^{\mathrm{I} X}(\mathrm{dppf})\right]$ (and biaryl) or $\left[\mathrm{Ni}^{\mathrm{II}}(\mathrm{Ar}) \mathrm{X}(\mathrm{dppf})\right]$; the ortho substituent of the aryl halide determines selectivity between these possibilities. A reactivity scale is presented in which a range of substrates is quantitatively ranked in order of the rate at which they undergo oxidative addition. The rate of oxidative addition is loosely correlated to conversion in prototypical cross-coupling reactions. Substrates that lead to $\mathrm{Ni}^{\mathrm{I}}$ products in kinetic experiments produce more homocoupling products under catalytic conditions.

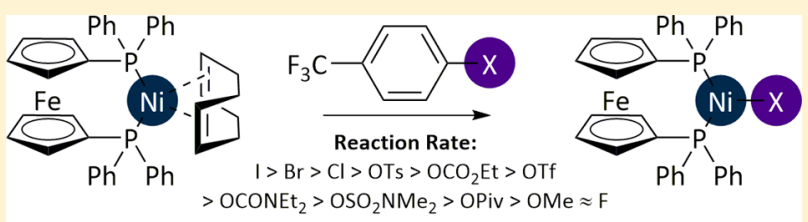

- Kinetic Studies and Exploration of Reaction Mechanism

- Origin of $\mathrm{Ni}(\mathrm{l})$ and Characterisation of $\mathrm{Ni}(\mathrm{l})$ by EPR spectroscopy

- Reactivity Scale for Oxidative Addition of Aryl Electrophiles

\section{INTRODUCTION}

Nickel catalysis is a rapidly growing field of synthetic chemistry; it has the potential to allow different and exciting reactivity to be exploited and might replace palladium in some reactions. ${ }^{1}$ Nickel oxidatively adds to a wide range of electrophiles beyond halides and triflates, ${ }^{2}$ and even ethers and fluorides can be deployed in cross-coupling reactions. ${ }^{3-5}$ The ability of nickel to achieve oxidation states +1 and +3 has enabled elegant and powerful tandem photocatalysis/cross-coupling methods; ${ }^{6,7}$ this reactivity manifold has the potential to be a rather general way to enable otherwise challenging $\mathrm{C}-\mathrm{O}$ and $\mathrm{C}-\mathrm{N}$ bond formations. ${ }^{8,9}$ However, our mechanistic understanding of nickel catalysis often lags far behind the development of useful synthetic protocols (Figure 1).

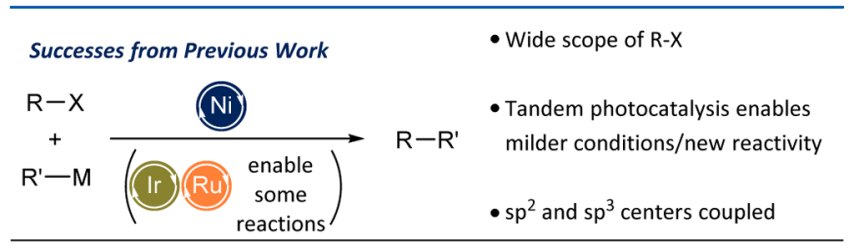

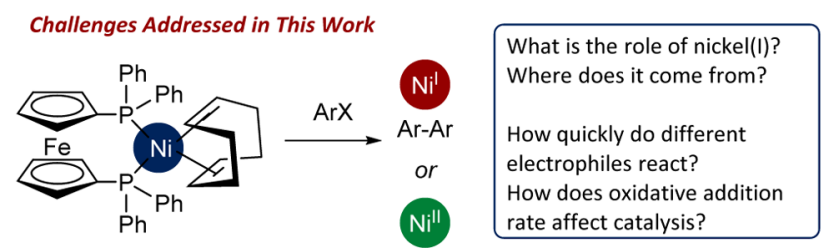

Figure 1. Previous achievements in nickel catalysis and challenges addressed here.
$\mathrm{Ni}^{0}$ complexes are highly reactive toward oxidative addition, ${ }^{10}$ but there are selectivity issues if densely functionalized molecular scaffolds are used that contain several potentially reactive sites. ${ }^{11}$ The number of accessible oxidation states complicates the mechanistic understanding of these reactions: some studies have implicated $\mathrm{Ni}^{\mathrm{I}}$ intermediates in catalysis, ${ }^{12,13}$ while others have conducted experimental and/or computational studies to rule them out. ${ }^{14-16}$ Recently, Hazari has detected $\mathrm{Ni}^{\mathrm{I}}$ complexes in prototypical Suzuki-Miyaura reactions, regardless of the $\mathrm{Ni}^{0}, \mathrm{Ni}^{\mathrm{I}}$, or $\mathrm{Ni}^{\mathrm{II}}$ (pre)catalyst used. ${ }^{17}$ A recent follow-up study showed that comproportionation competes with transmetalation in the cross-coupling of aryl sulfamates and implicated $\mathrm{Ni}^{\mathrm{I}}$-sulfamyl and $\mathrm{Ni}^{\mathrm{I}}$-aryl complexes as products of comproportionation. ${ }^{18}$ Schoenebeck has shown than the role and fate of $\mathrm{Ni}^{\mathrm{I}}$ species are highly dependent on the choice of both ligand and electrophile, with $[\mathrm{NiX}(\mathrm{bpy})]$ complexes being competent catalysts for some reactions of aryl bromides and iodides. ${ }^{19}$ These studies shed light on parts of a much larger puzzle, and much remains to be done.

We have conducted a detailed study of the oxidative addition of aryl halides to dppf $-\mathrm{Ni}^{0}$. This system was chosen for several reasons. dppf is inexpensive and widely available in most synthetic laboratories and so represents an accessible catalytic system. Ni/dppf catalyst systems are competent for many reactions, including Suzuki-Miyaura, ${ }^{17,18}$ Buchwald-Hartwig, $^{20}$ and trifluoromethylthiolation. ${ }^{11,15,19}[\mathrm{Ni}(\mathrm{COD})(\mathrm{dppf})]$ (1) is a thermally stable $\mathrm{Ni}^{0}$ complex that can be prepared on a

Received: March 17, 2017

Published: April 6, 2017 
sufficient scale in a straightforward manner. ${ }^{15}$ Finally, the presence of ${ }^{31} \mathrm{P}$ nuclides enables the use of NMR spectroscopy to monitor reactions in the presence of excess aryl halide, which swamps the ${ }^{1} \mathrm{H}$ NMR spectra. A number of synthetic protocols rely on the use of a ligand plus $\left[\mathrm{Ni}(\mathrm{COD})_{2}\right]^{20}$ and therefore $\left[\mathrm{Ni}(\mathrm{COD})(\mathrm{L})_{\mathrm{n}}\right]$ is formed in situ. More electron rich ligands such as $\mathrm{N}$-heterocyclic carbenes ${ }^{21,22}$ and trialkylphosphines are often used in the reactions of more challenging substrates, but complex 1 reacts with most electrophiles studied here (vide infra).

The primary aim of this study was to construct the first reactivity scale for oxidative addition to $\mathrm{Ni}^{0}$ that is based on a series of kinetic experiments conducted under the same conditions; to do this, it was important to study the oxidative addition step, rather than consider prototypical catalytic reactions in which the rate-determining step may not be oxidative addition, may change with different substrates, or where the (pseudo)halide will influence the rates of subsequent steps in the catalytic cycle. ${ }^{23}$ Importantly, while it is possible to appreciate which substrates undergo facile reaction and which substrates may be challenging to deploy from a reading of the synthetic chemistry literature, these typically consider prototypical reactions assessed by yield measurements; ${ }^{18,24}$ there is a real need to also consider the rate at which key processes occur because this provides valuable information about whether these are feasible on a time scale relevant to synthetic reactions. These quantitative data can then be used to select catalysts for particular reactions by considering how quickly they will activate the desired electrophile versus alternative sites in the molecule. These data can also highlight when useful selectivity cannot be achieved. To achieve the primary aim of this work, it was important to first elucidate the mechanism of oxidative addition to complex $\mathbf{1}$ and to elucidate the origin of $\mathrm{Ni}^{\mathrm{I}}$.

\section{RESULTS AND DISCUSSION}

Oxidative Addition of Aryl Halides. The oxidative addition reactions of $p-\mathrm{F}_{3} \mathrm{CC}_{6} \mathrm{H}_{4} \mathrm{X}, o-\mathrm{MeC}_{6} \mathrm{H}_{4} \mathrm{X}$, and $p$ $\mathrm{MeC}_{6} \mathrm{H}_{4} \mathrm{Cl}$ with $[\mathrm{Ni}(\mathrm{COD})(\mathrm{dppf})](\mathbf{1})$ were studied initially (Scheme 1 and Table $1 ; \mathrm{X}=\mathrm{I}, \mathrm{Br}, \mathrm{Cl}$ ). Reactions with para-

\section{Scheme 1. Oxidative Addition of Aryl Halides to} [Ni(COD)(dppf)] (1)
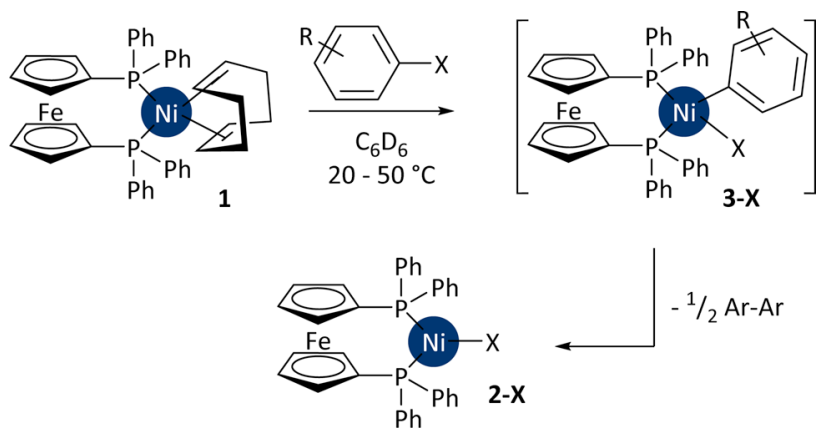

substituted aryl halides led to no diamagnetic complexes (as determined by ${ }^{31} \mathrm{P}$ NMR spectroscopy). Analysis of the isolated products of these reactions by EPR spectroscopy revealed the presence of $[\mathrm{NiX}(\mathrm{dppf})](\mathbf{2}-\mathrm{X})$ (vide infra). ${ }^{15,17,25} \mathrm{GC}-\mathrm{FID}$ and GC-MS analysis of the reaction of $p-\mathrm{F}_{3} \mathrm{CC}_{6} \mathrm{H}_{4} \mathrm{I}$ with 1 showed the presence of biaryl but no trifluorotoluene. The reactions of $o$-halotoluenes with 1 led initially to $[\mathrm{Ni}(\mathrm{o}$-tol $) \mathrm{X}(\mathrm{dppf})]$ (3$\mathrm{X}){ }^{26,27}$ subsequent GC-MS analysis of the reaction of 2 -
Table 1. Rate Constants for the Oxidative Addition of Selected Aryl Halides to [Ni(COD)(dppf)] (1) (0.022 mol $\mathrm{L}^{-1}$ in Benzene- $d_{6}$ )

\begin{tabular}{clccc} 
entry & substrate & $T(\mathrm{~K})$ & $k_{\text {obs }}\left(10^{-4} \mathrm{~s}^{-1}\right)$ & {$[\mathrm{ArX}]\left(\mathrm{mol} \mathrm{L}^{-1}\right)$} \\
1 & $o-\mathrm{MeC}_{6} \mathrm{H}_{4} \mathrm{I}$ & 303 & $5.04(7)$ & 0.44 \\
2 & $o-\mathrm{MeC}_{6} \mathrm{H}_{4} \mathrm{Br}$ & 323 & $6.90(6)$ & 0.44 \\
3 & $o-\mathrm{MeC}_{6} \mathrm{H}_{4} \mathrm{Cl}$ & 323 & $1.9(2)$ & 0.44 \\
4 & $p-\mathrm{MeC}_{6} \mathrm{H}_{4} \mathrm{Cl}$ & 323 & $2.26(3)$ & 0.44 \\
5 & $p-\mathrm{F}_{3} \mathrm{CC}_{6} \mathrm{H}_{4} \mathrm{I}$ & 293 & $7.8(1)$ & 0.44 \\
6 & $p-\mathrm{F}_{3} \mathrm{CC}_{6} \mathrm{H}_{4} \mathrm{Br}$ & 293 & $0.238(4)$ & 0.44 \\
7 & $p-\mathrm{F}_{3} \mathrm{CC}_{6} \mathrm{H}_{4} \mathrm{Br}$ & 323 & $10.2(1)$ & 0.44 \\
8 & $p-\mathrm{F}_{3} \mathrm{CC}_{6} \mathrm{H}_{4} \mathrm{Cl}$ & 323 & $2.39(3)$ & 0.44 \\
9 & $p-\mathrm{F}_{3} \mathrm{CC}_{6} \mathrm{H}_{4} \mathrm{Cl}$ & 323 & $2.89(1)$ & 0.55 \\
10 & $p-\mathrm{F}_{3} \mathrm{CC}_{6} \mathrm{H}_{4} \mathrm{Cl}$ & 323 & $3.42(6)$ & 0.66 \\
\hline
\end{tabular}

iodotoluene with 1 revealed both toluene and biaryl. Complex 1 does not undergo reaction with the internal standard used in these reactions $\left(\mathrm{OPCy}_{3}\right.$ or $\left.\mathrm{OPPh}_{3}\right)$ or the solvent, as confirmed by control experiments in the absence of aryl halide. The oxidative addition reaction is first order in aryl halide (Figure 2a).
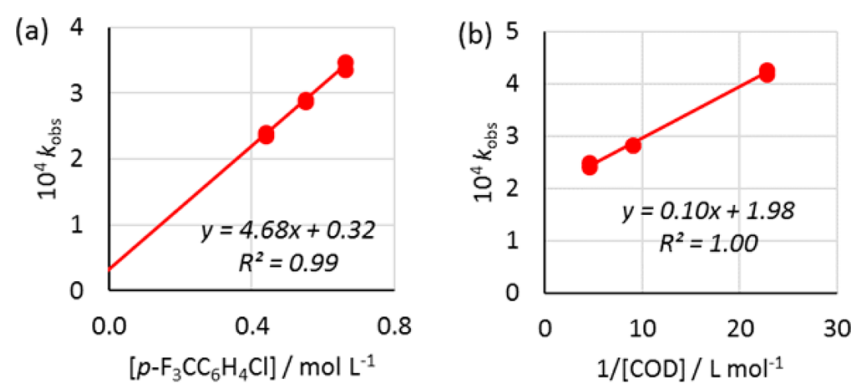

Figure 2. Plots of $k_{\text {obs }}$ versus (a) concentration of $p-\mathrm{F}_{3} \mathrm{CC}_{6} \mathrm{H}_{4} \mathrm{Cl}$ ( $p$ $\mathrm{F}_{3} \mathrm{C}-\mathrm{Cl}$ ) in the oxidative addition of $p-\mathrm{F}_{3} \mathrm{C}-\mathrm{Cl}$ to $\mathbf{1}$ and (b) the reciprocal of the concentration of 1,5-cyclooctadiene (COD) in the oxidative addition of $p-\mathrm{F}_{3} \mathrm{CC}_{6} \mathrm{H}_{4} \mathrm{Br}\left(p-\mathrm{F}_{3} \mathrm{C}-\mathrm{Br}\right)\left(0.44 \mathrm{~mol} \mathrm{~L}^{-1}\right)$ to 1 . All reactions were carried out with $0.022 \mathrm{~mol} \mathrm{~L}^{-1}[\mathrm{Ni}(\mathrm{COD})(\mathrm{dppf})](\mathbf{1})$ in benzene- $d_{6}$ at $50{ }^{\circ} \mathrm{C}$. Reactions were carried out in duplicate; each replicate is plotted separately.

As expected, the oxidative addition rate decreases in the order $\mathrm{I}>\mathrm{Br}>\mathrm{Cl}$. Experiments at lower temperatures were required to collect good-quality kinetic data for the reactions of aryl iodides due to the rapidity of the reaction. ${ }^{28}$ The reaction of $o$-chlorotoluene is ca. $10 \%$ slower than that of the para isomer. The reaction of 1 with $p-\mathrm{F}_{3} \mathrm{CC}_{6} \mathrm{H}_{4} \mathrm{Br}$ was studied at 20 and $50{ }^{\circ} \mathrm{C}$ so that the rate constants could be used to quantify the relative reactivity: this is $143: 4: 1$ for $\mathrm{I}: \mathrm{Br}: \mathrm{Cl}$ (for the $p$ trifluoromethyl substrates), which compares to 100:3:2 for the reaction of halobenzenes with $\left[\mathrm{Ni}\left(\mathrm{PEt}_{3}\right)_{4}\right]$ in $\mathrm{THF}^{29}$ and 400:2:1 with $\left[\mathrm{Ni}\left(\mathrm{PPh}_{3}\right)_{4}\right]$ in benzene. ${ }^{30}$

Added COD inhibits the reaction (Figure 2b); therefore, it must be displaced from the complex before oxidative addition can occur. Trifluoromethylthiolation reactions catalyzed by 1 have been found to be faster than those catalyzed by a mixture of $\left[\mathrm{Ni}(\mathrm{COD})_{2}\right]$ and dppf, most likely due to the additional 1 equiv of COD inhibiting the latter reaction. ${ }^{15}$ For the oxidative addition reactions considered here, a plot of $\ln [\mathrm{COD}]$ versus $\mathrm{k}_{\mathrm{obs}}$ has a slope of ca. -0.3 and Figure $2 \mathrm{~b}$ shows a nonzero intercept; thus, the kinetic behavior is not simply inverse first order. Arenes are known to be competent ligands for $\mathrm{Ni}^{0}$ complexes, ${ }^{31}$ and so a plausible first step would be displacement 
of COD by the aryl halide. $\left[{ }^{1} \mathrm{H},{ }^{1} \mathrm{H}\right]$ EXSY experiments were carried out to investigate the rate of exchange of free COD with the COD bound to 1 ; no exchange was observed at $10-50{ }^{\circ} \mathrm{C}$ in benzene- $d_{6}$, ruling out a dissociative mechanism in which a vacant site is generated. ${ }^{32}$ An associative mechanism is unlikely due to the lack of space around the metal center; ${ }^{15,19}$ therefore, an interchange mechanism in which incoming substrate displaces COD is most likely.

If the overall reaction is considered as a reversible ligand exchange (with rate constants $k_{1}$ and $k_{-1}$ ) followed by irreversible oxidative addition (with rate constant $k_{2}$ ), the steady-state approximation can be used to derive eq 1 . At low concentrations of COD, $k_{2} \gg k_{-1}$ [COD] and the expression can be simplified to eq 2 . At high [COD], $k_{-1}[\mathrm{COD}] \gg k_{2}$ and eq 3 can be derived. The alternative, an equilibrium approximation in which the ligand exchange rate does not influence the rate of reaction, is not consistent with our results because this should lead to good inverse first-order behavior in [COD] across all COD concentrations (i.e., eq 3), not just at higher [COD]. Our results are consistent with an increasing contribution from the $k_{-1}[\mathrm{COD}]$ term as [COD] increases and, therefore, with eq 1 .

$$
\begin{aligned}
-\mathrm{d}[\mathbf{1}] / \mathrm{d} t & =\left(k_{1} k_{2}[\mathbf{1}][\mathrm{ArX}]\right) /\left(k_{-1}[\mathrm{COD}]+k_{-2}\right) \\
-\mathrm{d}[\mathbf{1}] / \mathrm{d} t & =k_{1}[\mathbf{1}][\mathrm{ArX}] k_{\text {obs }}=k_{1}[\mathrm{ArX}] \\
-\mathrm{d}[\mathbf{1}] / \mathrm{d} t & =\left(K_{1} k_{2}[\mathbf{1}][\mathrm{ArX}]\right) /[\mathrm{COD}] k_{\text {obs }} \\
& =\left(K_{1} k_{2}[\mathrm{ArX}]\right) /[\mathrm{COD}]
\end{aligned}
$$

COD displacement by alkene ligands is faster than oxidative addition. 1 reacts with 1 equiv of styrene at room temperature within a few minutes to form an equilibrium mixture that consists of a 1:20 mixture of 1 and $\left[\mathrm{Ni}\left(\eta^{2}\right.\right.$-styrene)(dppf)]. Kinetic studies with 20 equiv of $p$-chlorostyrene at $50{ }^{\circ} \mathrm{C}$ yielded an analogous species immediately after substrate addition; this species then decayed via a pseudo-first-order process with a rate similar to that for $p$-chlorotoluene ([2.63(1)] $\times 10^{-4}$ and $[2.39(3)] \times 10^{-4} \mathrm{~s}^{-1}$, respectively). This is consistent with a pre-equilibrium followed by ratedetermining oxidative addition. The oxidative addition of alkene-containing aryl halides to $\left[\mathrm{Ni}\left(\mathrm{PEt}_{3}\right)_{4}\right]$ is occurs via $\left[\mathrm{Ni}\left(\eta^{2}\right.\right.$-alkene $\left.)\left(\mathrm{PEt}_{3}\right)_{2}\right]$ and a "ring-walking" process. ${ }^{33}$ As the rate of ligand exchange is involved in the rate expression (eq 1), it might be expected that substrates bearing good ligands (such as 4-chlorostyrene) might react much more quickly than simpler aryl halides. However, the nickel center must still leave the alkene to "ring-walk" to the $\mathrm{C}-\mathrm{X}$ bond prior to oxidative addition, which presents an energetic barrier.

A Hammett analysis ${ }^{34}$ was carried out using the following para-substituted substrates: chloroanisole, chlorotoluene, chlorobenzene, methyl chlorobenzoate, and chloro(trifluoromethyl)benzene. $^{35}$ The resulting plot shows that for electron-rich substrates $\rho=1.2$ and that there appears to be an opposite trend for electron-poor substrates (Figure 3).

This outcome differs significantly from a number of relevant examples in the literature. The oxidative addition of aryl chlorides to $\left[\mathrm{Ni}\left(\mathrm{PEt}_{3}\right)_{4}\right]$ via rate-determining electron transfer had $\rho=5.4 .^{29}$ For oxidative addition to $\left[\mathrm{Ni}\left(\mathrm{PPh}_{3}\right)_{4}\right]$, substrates with electron-donating substituents had similar reaction ratessuggestive of a common rate-determining step such as ligand dissociation from nickel-while a set of electron-withdrawing substrates had $\rho=8.8 .^{30}$ The $S_{N}$ Ar-like oxidative addition of aryl halides to a $\mathrm{Pd}^{0}$ complex via a Meisenheimer intermediate had $\rho=5.2 .^{36}$

Our results are consistent with a change in rate-determining step or with the contributions of different processes to determining the overall rate. A plausible explanation is that the electron-poor aryl halides which are better $\eta^{2}$ ligands for electron-rich metal centers displace the COD more readily or that the equilibrium for ligand exchange lies further toward a $\left[\mathrm{Ni}\left(\eta^{2}-\mathrm{ArX}\right)(\mathrm{dppf})\right]$ complex. However, the oxidative addition step from this intermediate may be faster for electron-rich aryl halides. These two competing effects were revealed in a DFT study of the oxidative addition of aryl halides to $\left[\mathrm{Pd}\left(\mathrm{P}^{t} \mathrm{Bu}_{3}\right)_{2}\right]$ via $\left[\operatorname{Pd}\left(\eta^{2}\right.\right.$-arene $\left.)\left(\mathrm{P}^{t} \mathrm{Bu}_{3}\right)\right]$ complexes. ${ }^{37}$ To further probe this possibility, the reactions of $p-\mathrm{MeOC}_{6} \mathrm{H}_{4} \mathrm{Br}$ with 1 in the presence of different concentrations of COD were monitored by ${ }^{31} \mathrm{P}$ NMR experiments. By $k_{\text {rel }}$ for each experiment being defined as $k_{\mathrm{obs}}$ divided by $k_{\mathrm{obs}}$ in the absence of added COD, the plot in Figure 4 was constructed. This shows that the more

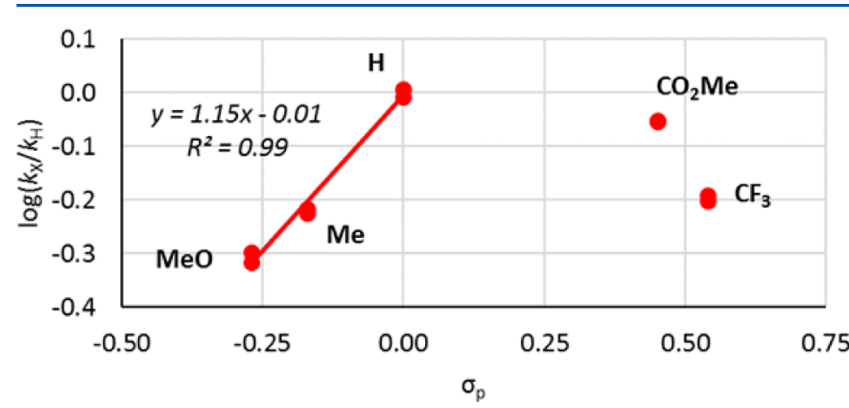

Figure 3. Hammett treatment for the oxidative addition of $p-\mathrm{YC}_{6} \mathrm{H}_{4} \mathrm{Cl}$ $\left(0.44 \mathrm{~mol} \mathrm{~L}^{-1}\right)$ to $[\mathrm{Ni}(\mathrm{COD})(\mathrm{dppf})](\mathbf{1})\left(0.022 \mathrm{~mol} \mathrm{~L}^{-1}\right)$ in benzene$d_{6}$ at $50{ }^{\circ} \mathrm{C}$. Each experiment was performed in duplicate, and each replicate is plotted separately.

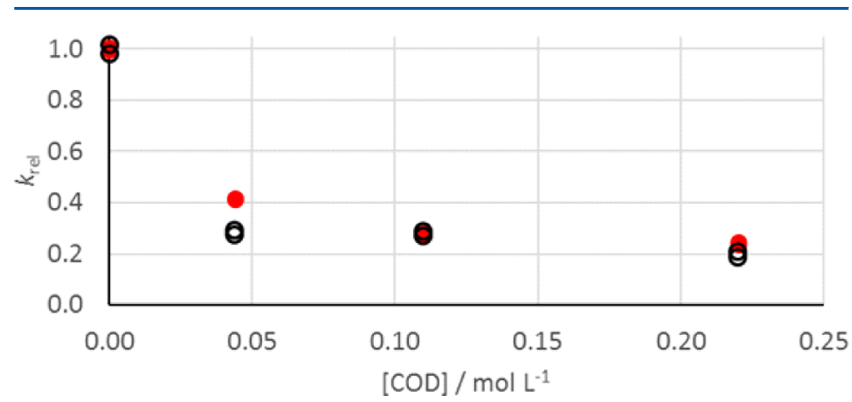

Figure 4. Plot of $k_{\mathrm{rel}}\left(k_{\mathrm{obs}}\right.$ divided by $k_{\mathrm{obs}}$ in the absence of COD) versus [COD] for the reactions of (i) $p-\mathrm{F}_{3} \mathrm{CC}_{6} \mathrm{H}_{4} \mathrm{Br}$ (filled red circles) and (ii) $p-\mathrm{MeOC}_{6} \mathrm{H}_{4} \mathrm{Br}$ (open black circles) with 1 in benzene- $d_{6}$ $\left(0.022 \mathrm{~mol} \mathrm{~L}^{-1}\right)$ at $50{ }^{\circ} \mathrm{C}$. The concentration of aryl halide was 0.44 $\mathrm{mol} \mathrm{L}^{-1}$ in each case. All reactions were performed in duplicate, and all replicates are plotted.

electron rich substrate, which is a poorer ligand for the electron-rich $\mathrm{d}^{10} \mathrm{Ni}^{0}$ complex, is more sensitive to the addition of COD; 2 equiv of COD (relative to 1 ) decreases the rate of oxidative addition of $p-\mathrm{F}_{3} \mathrm{CC}_{6} \mathrm{H}_{4} \mathrm{Br}$ by $58 \%$ but decreases the rate of oxidative addition of $p-\mathrm{MeOC}_{6} \mathrm{H}_{4} \mathrm{Br}$ by $71 \%$. These results are consistent with our proposal for the switch in ratedetermining step.

The reactions of $p-\mathrm{F}_{3} \mathrm{CC}_{6} \mathrm{H}_{4} \mathrm{Br}$ with $\mathbf{1}$ at temperatures from 20 to $50{ }^{\circ} \mathrm{C}$ (inclusive) were used to obtain activation parameters: $\Delta H^{\ddagger}=24(1) \mathrm{kcal} \mathrm{mol}^{-1}$ and $\Delta S^{\ddagger}=0(3) \mathrm{cal} \mathrm{K}^{-1}$ $\mathrm{mol}^{-1}$. The displacement of COD is involved in the overall reaction; therefore, $\Delta S^{\ddagger}$ is the sum of terms for COD exchange 
Scheme 2. Mechanisms for the Oxidative Addition of Aryl Halides to $[\mathrm{Ni}(\mathrm{COD})(\mathrm{dppf})](1)$

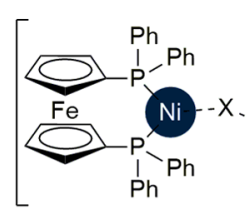<smiles>[R][CH][CH+]c1ccc(C)cc1</smiles>
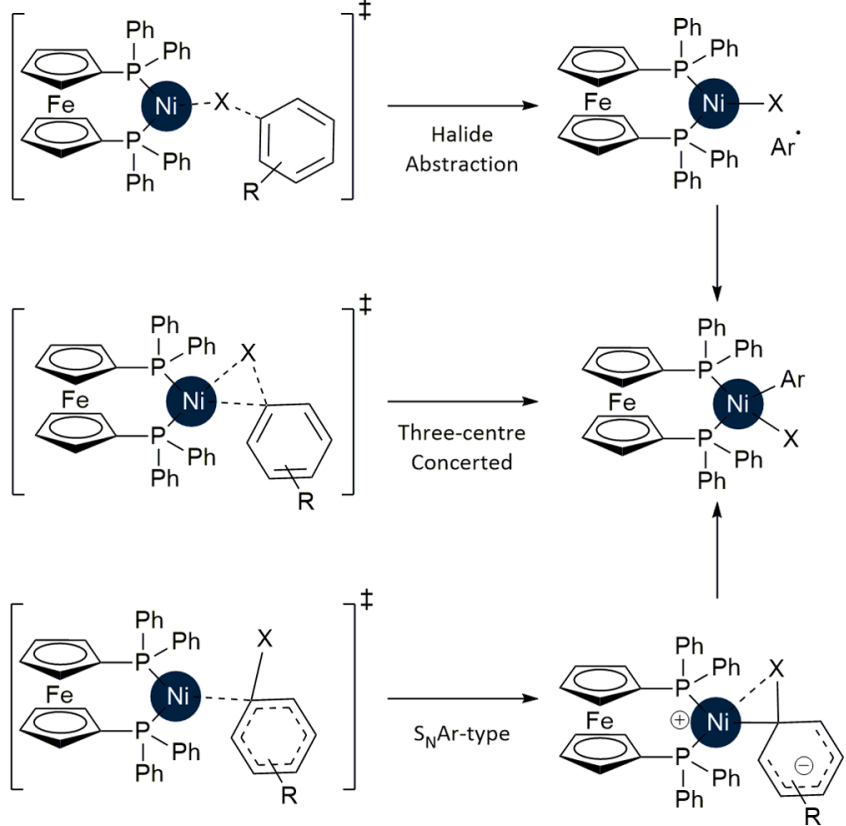

and oxidative addition. The small $\Delta S^{\ddagger}$ rules out bimetallic oxidative addition. Three common mechanisms for the oxidative addition of aryl halides to zerovalent $\mathrm{d}^{10}$ transition metals are illustrated in Scheme 2. ${ }^{38}$ Oxidative addition to anionic $\mathrm{Pd}^{0}$ is known; ${ }^{39}$ however, anionic $\mathrm{Ni}^{0}$ intermediates are not considered here because no ions are added to these reactions, the medium is of low polarity, and it is known that the addition of anions to the oxidative addition reactions of $\mathrm{dppf}-\mathrm{Pd}^{0}$ complexes does not lead to a rate enhancement. ${ }^{40,41}$ On the basis of literature reports, the shallow Hammett plot is not consistent with electron transfer mechanisms or an $S_{N} A r-$ type mechanism $(\rho>$ ca. 4$)$. A radical chain mechanism ${ }^{42}$ can be excluded because the oxidative addition reaction proceeds in the presence of 1 equiv of TEMPO. A concerted three-center transition state is consistent with our results and with the relatively low $\Delta S^{\ddagger}$ (cf. 2(1) $\mathrm{cal} \mathrm{K}^{-1} \mathrm{~mol}^{-1}$ for the oxidative addition of aryl iodides to $\left.\left[\mathrm{Pd}\left(\mathrm{PPh}_{3}\right)_{4}\right]\right) ;{ }^{43}$ such transition states have been characterized using DFT techniques. ${ }^{11,15} \mathrm{~A}$ related concerted five-center transition state for the oxidative addition of aryl sulfamates to $\mathrm{dppf}-\mathrm{Ni}^{0}$ has also been reported. $^{18}$

Oxidative Addition of Other Aryl Electrophiles. A great strength of nickel catalysis is the ability to deploy a range of substrates beyond the halides and triflates typically used in palladium catalysis. ${ }^{1-3,44}$ Nickel has been used to achieve the cross-coupling of aryl sulfonates and sulfamates at room temperature, $^{45,46}$ enable the deployment of carbamateswhich are useful directing groups for ortho-lithiation reactions) -in cross-coupling catalysis, ${ }^{47}$ and even to allow aryl ethers ${ }^{48,49}$ and aryl fluorides ${ }^{4,50}$ to be used in crosscoupling. Esters can be used in cross-coupling ${ }^{51}$ and decarboxylative cross-coupling ${ }^{52}$ reactions, depending on the regioisomer.

There has not yet been a quantitative experimental comparison of the reactivity of this varied palette of substrates in oxidative addition to $\mathrm{Ni}^{0}$; this limits our understanding of the reactivity of $\mathrm{Ni}^{0}$. The best examples of experimental comparisons in the literature are only qualitative, consider only halides, ${ }^{29,30}$ or rely on the use of prototypical reactions which have complex catalytic cycles and which might be influenced by various other factors. ${ }^{24,53-55}$ Liu has reported a computational study of the activation of various $\mathrm{Ph}-\mathrm{X}$ bonds by $\left[\mathrm{Ni}\left(\mathrm{PMe}_{3}\right)\right]$, showing that the barrier decreases in the order $\mathrm{X}=\mathrm{OMe}>\mathrm{F}>\mathrm{OAc}>\mathrm{OMs}>\mathrm{NHAc}>\mathrm{OTs}>\mathrm{SAc}>\mathrm{Cl}>$ OTf $>$ Br. $^{56}$ Schoenebeck has used DFT calculations to compare the reactivity of different electrophiles toward dppf$\mathrm{Ni}^{0}$, finding that the barrier decreases in the order OMe $>$ OPiv $>$ OTs > OMs > OTf. ${ }^{11}$ Most of these studies consider reactions via mono- rather than bisphosphine $\mathrm{Ni}^{0}$ complexes; thus, they cannot necessarily be extrapolated to dppf $-\mathrm{Ni}^{0}$ or other such species. Here, this gap in the literature is addressed by quantitatively ranking these substrates in the order of the rate at which they undergo oxidative addition to $[\mathrm{Ni}(\mathrm{COD})$ (dppf)] (1).

The following $p-\mathrm{F}_{3} \mathrm{CC}_{6} \mathrm{H}_{4} \mathrm{X}$ substrates were prepared or purchased: $\mathrm{X}=\mathrm{OTf}, \mathrm{OTs}, \mathrm{OSO}_{2} \mathrm{NMe}_{2}, \mathrm{OPiv}, \mathrm{OCO}_{2} \mathrm{Et}$, $\mathrm{OCONEt}_{2}, \mathrm{OMe}, \mathrm{F}$. Many of these substrates underwent reaction only very slowly at $50{ }^{\circ} \mathrm{C}$ and so were studied at $70{ }^{\circ} \mathrm{C}$ in toluene- $d_{8}$ instead (Table 2). ${ }^{57}$ Rate constants for the

Table 2. Rate Constants for the Oxidative Addition of Selected Aryl (Pseudo)halides $\left(0.44 \mathrm{~mol} \mathrm{~L}^{-1}\right)$ to $[\mathrm{Ni}(\mathrm{COD})(\mathrm{dppf})](\mathbf{1})\left(0.022 \mathrm{~mol} \mathrm{~L}^{-1}\right.$ in Benzene- $d_{6}$ at 293 or $323 \mathrm{~K}$ or in Toluene- $d_{8}$ at $\left.343 \mathrm{~K}\right)$

\begin{tabular}{|c|c|c|c|}
\hline entry & $\mathrm{X}$ in substrate $\left(p-\mathrm{F}_{3} \mathrm{CC}_{6} \mathrm{H}_{4} \mathrm{X}\right)$ & $T(\mathrm{~K})$ & $k_{\text {obs }}\left(10^{-4} \mathrm{~s}^{-1}\right)$ \\
\hline $1^{a}$ & I & 293 & $7.8(1)$ \\
\hline $2^{a}$ & $\mathrm{Br}$ & 293 & $0.238(4)$ \\
\hline $3^{a}$ & $\mathrm{Br}$ & 323 & $10.2(1)$ \\
\hline $4^{a}$ & $\mathrm{Cl}$ & 323 & $2.39(3)$ \\
\hline 5 & OTs & 323 & $0.82(1)$ \\
\hline 6 & OTs & 343 & $10.6(4)$ \\
\hline 7 & $\mathrm{OCO}_{2} \mathrm{Et}$ & 343 & $4.9(2)$ \\
\hline 8 & OTf & 343 & $4.62(2)$ \\
\hline 9 & $\mathrm{OCONEt}_{2}$ & 343 & $2.79(7)$ \\
\hline 10 & $\mathrm{XOSO}_{2} \mathrm{NMe}_{2}$ & 343 & $1.9(1)$ \\
\hline 11 & OPiv & 343 & $1.0(1)$ \\
\hline 12 & $\mathrm{OMe}$ & 343 & $<0.01^{b}$ \\
\hline 13 & $\mathrm{~F}$ & 343 & $<0.01^{b}$ \\
\hline
\end{tabular}

${ }^{a}$ From Table $1 .{ }^{b}$ Estimated from ca. $25 \%$ conversion after $48 \mathrm{~h}$.

fluoride and the methyl ether are estimated (ca. 25\% conversion after $48 \mathrm{~h}$ ) because the reaction is too slow to monitor in situ. ${ }^{58}$ The tosylate and bromide were each studied at two temperatures, so that $k_{\text {obs }}$ could be used to construct a reactivity scale (Figure 5).

This has allowed a range of electrophiles to be ranked in the order of their rate of oxidative addition to $\mathrm{Ni}^{0}$ for the first time. It shows that most electrophiles will undergo reaction with $\mathbf{1}$ in the presence of aryl ethers and aryl fluorides; it also allows the identification of situations where synthetically useful selectivity can be achieved between electrophiles (i.e., >10-fold rate difference). Figure 5 also allows for comparisons with palladium catalysis; the rate of oxidative addition to $\mathrm{Pd}^{0}$ typically decreases in the order $\mathrm{I}>\mathrm{Br} \approx \mathrm{OTf}>\mathrm{OTs}>\mathrm{Cl}^{41,59-61}$ In reactions with 1 , the rate of oxidative addition decreases in the order $\mathrm{Br}>\mathrm{Cl}>$ OTs $>$ OTf.

Aryl sulfamates undergo oxidative addition to 1 more slowly than aryl carbamates, and tosylates undergo oxidative addition more slowly than chlorides. These results are in contrast to 
<smiles></smiles><smiles></smiles><smiles>CCNC(=O)Oc1ccc(C(F)(F)F)cc1</smiles><smiles>O=S(=O)(Oc1ccc(C(F)(F)F)cc1)OS(=O)(=O)C(F)(F)F</smiles><smiles>CCOC(=N)Oc1ccc(C(F)(F)F)cc1</smiles><smiles>O=S(=O)(O)Oc1ccc(C(F)(F)F)cc1</smiles><smiles>FC(F)(F)c1ccc(Cl)cc1</smiles><smiles></smiles>
10

Figure 5. Reactivity scale for the oxidative addition of aryl electrophiles to [Ni(COD)(dppf)] (1).

reactions conducted by Houk, Garg, and Snieckus ${ }^{55}$ and by Monteiro, ${ }^{53}$ respectively. However, the literature studies considered the outcomes of cross-coupling reactions-not just the reaction of the substrate with $\mathrm{Ni}^{0}$ - and used $\left[\mathrm{NiCl}_{2}\left(\mathrm{PCy}_{3}\right)_{2}\right]$ as the catalyst, which may exhibit different selectivity. The stability of complexes of the form $[\mathrm{Ni}(\mathrm{Ar}) \mathrm{X}$ $\left.(\mathrm{L})_{\mathrm{n}}\right]$ under the reaction conditions, and the rate at which they undergo transmetalation, may be a function of ligand $\mathrm{X}$.

To explore why triflates react more slowly than tosylates, activation parameters were determined for these two oxidative addition reactions. $\Delta H^{\ddagger}\left(\mathrm{kcal} \mathrm{mol}^{-1}\right)$ increases in the order $\mathrm{Br}$ $24(1)<$ OTs $28(2)<$ OTf $31(2) . \Delta S^{\ddagger}$ is almost 0 for bromide and tosylate $\left(0(3)\right.$ and $8(5) \mathrm{cal} \mathrm{K}^{-1} \mathrm{~mol}^{-1}$, respectively) yet larger for triflate $\left(16(7) \mathrm{cal} \mathrm{K}^{-1} \mathrm{~mol}^{-1}\right)$, indicative of a change in the nature of the transition state. Complex 1 reacts with 1 naphthyl triflate to form a species consistent with $[\mathrm{Ni}(1-$ naphthyl)(OTf)(dppf)], but the ${ }^{31} \mathrm{P}\left\{{ }^{1} \mathrm{H}\right\}$ signals are very broad, suggesting a fluxional species; reaction in the presence of tetran-octylammonium bromide yields the same signals initially, but a pair of sharp doublets appears later. The latter are consistent with the formation of $[\mathrm{NiBr}(1-$ naphthyl $)(\mathrm{dppf})]$. Aryl triflates form cationic complexes upon oxidative addition to [Pd$\left.\left(\mathrm{PPh}_{3}\right)_{4}\right]$ or $\left[\mathrm{Pd}(\mathrm{dppf})\left(\eta^{2}\right.\right.$-methyl methacrylate $\left.)\right]$, and the results here are consistent with a similar scenario with complex 1. Alternatively, there may be different contributions from three- and five-centered transition states for OTs and OTf. Either way, the larger value of $\Delta S^{\ddagger}$ results from the fact that the triflate moiety is more loosely bound or is outer sphere, and so the oxidative addition TS is likely to be quite different.

Products of Oxidative Addition. Complex 1 reacts with para-substituted aryl (pseudo)halides to form $\mathrm{Ni}^{\mathrm{I}}$ products plus biaryl; the latter products were detected by GC-FID and/or GC-MS analysis. Archetypal $[\mathrm{NiCl}(\mathrm{dppf})]$ (2-Cl), which has been isolated and spectroscopically characterized by Schoenebeck, ${ }^{15}$ gives a spectroscopic benchmark from which to compare the other $\mathrm{Ni}^{\mathrm{I}}$ species in the series. ${ }^{62}{ }^{1} \mathrm{H}$ NMR analysis of samples from kinetic experiments with $p$-trifluoromethylphenyl chloride and $p$-chlorotoluene revealed characteristic signals corresponding to this species. ${ }^{17}$ Complex 2-Cl was isolated from oxidative addition reactions repeated on a slightly larger scale. It gave an EPR signal characteristic of a $\mathrm{d}^{9}$ metal with $g_{\text {iso }}=2.172$, significantly larger than that of the free electron $\left(g_{\mathrm{e}}=2.0023\right){ }^{63-67}$ Hyperfine coupling from two equivalent ${ }^{31} \mathrm{P}$ nuclei $(I=1 / 2,100 \%$ abundance $)$ of the chelating dppf ligand gives a triplet splitting pattern (Figure 6). $[\mathrm{NiBr}(\mathrm{dppf})](\mathbf{2}-\mathrm{Br})$ and $[\mathrm{NiI}(\mathrm{dppf})](2-\mathrm{I})$ were also detected in the ${ }^{1} \mathrm{H}$ NMR spectra of the corresponding kinetic experiments and were characterized by methods including Xray crystallography and EPR spectroscopy. The solid-state structures of $2-\mathbf{B r}$ and $2-\mathrm{I}$ obtained under our crystallization

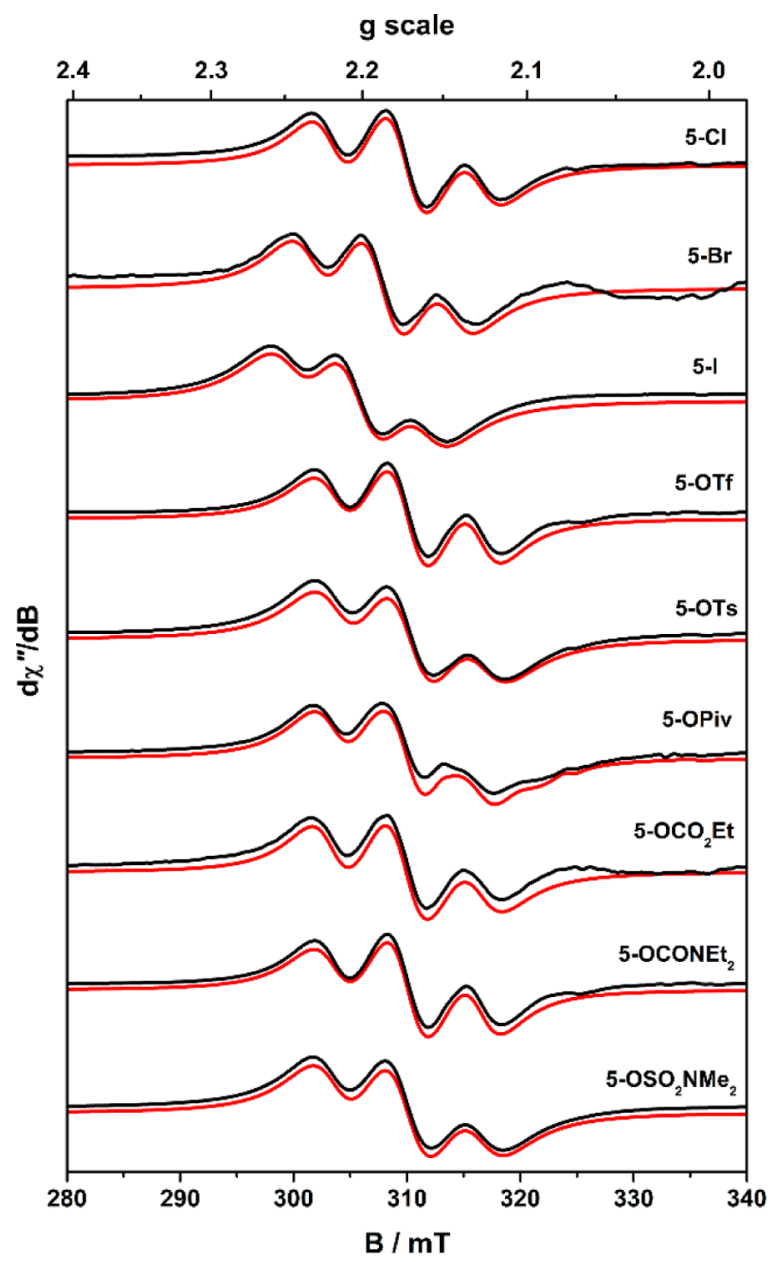

Figure 6. X-band EPR spectra for $[\mathrm{NiX}(\mathrm{dppf})]$ complexes (2-X) recorded at ambient temperature. Experimental data are depicted by the black traces; simulations are depicted by the red lines. The simulation parameters can be found in Table S5 in the Supporting Information.

conditions were found to be centrosymmetric halide-bridged dimers (see Figure 7 for $(\mathbf{2}-\mathbf{B r})_{2}$ and the Supporting Information for $\left.(2-\mathrm{I})_{2}\right)$; the $\mathrm{X}$-ray crystal structures of the monomer of $2-\mathbf{B r}$ and the dimer $(2-\mathrm{I})_{2}$ have recently been reported. ${ }^{18,19}$ The preference for the larger halides to dimerize is reflected in their EPR spectra, where comparatively weaker signals were obtained for $\mathbf{2}-\mathbf{B r}$ and 2 -I dissolved in THF. The use of a coordinating solvent was necessary to generate a measurable amount of monomeric species from the diamagnetic dimeric form. Noticeably, there is a significant $g$ shift commensurate with the larger spin-orbit coupling constants of 


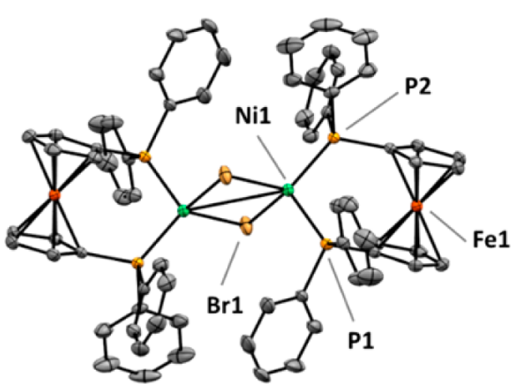

Figure 7. Molecular structure of $[\mathrm{Ni}(\mu \text {-Br })(\mathrm{dppf})]_{2}(2-\mathrm{Br})_{2}$ determined by $\mathrm{X}$-ray crystallography, with thermal ellipsoids drawn at $50 \%$ probability and hydrogen atoms excluded.

these heavier halides and a concomitant decrease in the ${ }^{31} \mathrm{P}$ hyperfine coupling constant in comparison to $\mathbf{2 - C l}$, given the more covalent bonding with $\mathrm{Br}$ and I (see Table S5 in the Supporting Information).

Several new $\mathrm{Ni}^{\mathrm{I}}$ complexes, generated in situ in toluene, were similarly characterized by EPR at ambient temperature (Figure 6). The sulfamate complex $\mathbf{2}-\mathbf{O S O}_{2} \mathbf{N M e}$ has been observed spectroscopically in a recently published study. ${ }^{18}$ As all substrates other than the halides provide an oxygen donor ligand, $g$ and $A$ remain invariant across the series, nearly identical with those of the archetypical 2-Cl (Table S5 in the Supporting Information). Unlike the halides, the availability of adjacent donor atoms presents the possibility of a bidentate coordination mode, changing the symmetry from trigonal planar to pseudotetrahedral. Only the EPR spectra of 2-OPiv displayed overlapping signals; the simulation was achieved by including $16 \%$ of a second species with smaller $g=2.144$ but the same $A$ value. This signal could arise from tetrahedral $\mathrm{Ni}^{\mathrm{I}}$, ${ }^{68}$ as pivalate is more likely than the other substrates to chelate the metal ion. It is possible that the shift in $g$ for the other ligands is not large enough to distinguish the tetrahedral complex from the dominant trigonal complex. A more detailed spectroscopic study is currently underway to elucidate the molecular and electronic structures of these new $\mathrm{Ni}^{\mathrm{I}}$ complexes. Nevertheless, these data are sufficient at this point to show that the products of oxidative addition of $p-\mathrm{F}_{3} \mathrm{CC}_{6} \mathrm{H}_{4} \mathrm{X}$ compounds to 1 are $\mathrm{Ni}^{\mathrm{I}}$ complexes 2-X.

Complex 1 reacts with the carbonate $\left(p-\mathrm{F}_{3} \mathrm{CC}_{6} \mathrm{H}_{4} \mathrm{OCO}_{2} \mathrm{Et}\right)$ at $70{ }^{\circ} \mathrm{C}$ to form a transient (unidentified) diamagnetic complex $\left(\delta_{\mathrm{P}} 22.4 \mathrm{ppm}\right)$ and signals consistent with $\mathrm{Ni}^{\mathrm{I}}\left(\delta_{\mathrm{H}} 12.5\right.$ ppm, $\omega_{1 / 2}=$ ca. $\left.200 \mathrm{~Hz}\right)$. The formation of a paramagnetic species was evidenced by a weak signal in the EPR spectrum of this reaction mixture in toluene (Figure 6). The $g$ and $A$ values matched the other spectra in this study, consistent with an $O$ donor carbonate ligand completing the $\mathrm{Ni}^{\mathrm{I}}$ coordination sphere (Table S5 in the Supporting Information).

Reactions with ortho-substituted aryl halides lead to species consistent with $[\mathrm{Ni}(\mathrm{Ar}) \mathrm{X}(\mathrm{dppf})]$ (e.g., Figure $8 ; \mathrm{OPPh}_{3}$ is an internal standard), ${ }^{26,27}$ confirmed by comparison with an authentic sample of $[\mathrm{NiCl}(o-$ tol $)(\mathrm{dppf})]$ (3-Cl). However, these complexes do not persist under the reaction conditions, and the concentration present at the end of the reaction does not account for all of the $\mathbf{1}$ that was present at the start. GC-MS analysis of reaction mixtures reveals the presence of both toluene and a species consistent with 2,2'-dimethylbiphenyl.

Experiments were carried out to identify the factors that influence the stability of $[\mathrm{Ni}(\mathrm{Ar}) \mathrm{X}(\mathrm{dppf})] ; 1$ - and 2bromonaphthalenes have similar electronic properties but different steric environments around the $\mathrm{C}-\mathrm{Br}$ bond. The

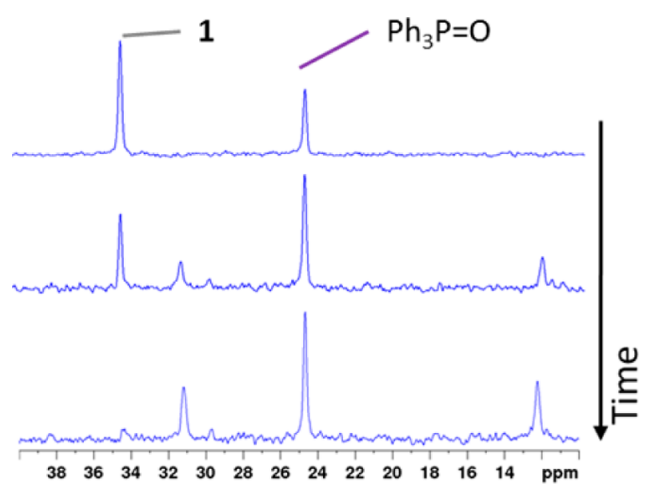

Figure 8. Partial ${ }^{31} \mathrm{P}$ NMR spectra from the reaction of $[\mathrm{Ni}(\mathrm{COD})$ (dppf)] (1) $\left(0.022 \mathrm{~mol} \mathrm{~L}^{-1}\right)$ with $o-\mathrm{MeC}_{6} \mathrm{H}_{4} \mathrm{I}\left(0.44 \mathrm{~mol} \mathrm{~L}^{-1}\right)$ in benzene- $d_{6}$ at $50{ }^{\circ} \mathrm{C}$, before substrate addition (top), after $1 \mathrm{~h}$ (middle), and after $2.5 \mathrm{~h}$ (bottom). $\mathrm{Ph}_{3} \mathrm{PO}$ is an internal standard.

oxidative addition reactions of 1- and 2-bromonaphthalene are (respectively) 4 and 6 times faster than that of $p$ (trifluoromethyl)bromobenzene in benzene- $d_{6}$ at $20{ }^{\circ} \mathrm{C}\left(k_{\text {obs }}\right.$ $=[0.97(5)] \times 10^{-4},[1.59(4)] \times 10^{-4}$, and $[0.238(4)] \times 10^{-4}$ $\mathrm{s}^{-1}$, respectively), consistent with previously observed reactivity differences. $^{18,49}$ The 1 -isomer reacts with 1 to form a Ni ${ }^{\mathrm{II}}$ complex; GC analysis showed naphthalene-potentially from decomposition of this complex in the GC inlet-and traces of 1,1'-binaphthyl. The 2 -isomer reacts to produce no diamagnetic phosphine-containing species, while GC analysis revealed no naphthalene but quantities of 2,2'-binaphthyl. Only paramagnetic products were obtained when complex 1 was exposed to $o$-bromofluorobenzene or $p$-bromofluorobenzene; thus, an ortho substituent larger than fluorine is necessary to stabilize $\mathrm{Ni}^{\mathrm{II}}$. There has been discussion of this "ortho effect" in the literature, with the most likely explanation being steric protection of the nickel center. ${ }^{69,70}$

Origin of $\mathrm{Ni}^{\prime}$ Products. $\left[\mathrm{Ni}(\mathrm{Ar}) \mathrm{X}(\mathrm{L})_{n}\right]$ complexes are more stable when $\mathrm{Ar}$ is ortho-substituted, ${ }^{71-73}$ although ligand choice is crucial. ${ }^{74}$ A thorough understanding of the effect of structure on the reactivity of these types of complex is important because these serve as intermediates, not only in nickel-catalyzed cross-coupling but also in the reductive crosscoupling of aryl and alkyl electrophiles, ${ }^{75}$ and as potential intermediates in tandem nickel/photoredox-mediated reactions ${ }^{6,7,76}$ or in new reactions currently under development. ${ }^{77}$

The oxidative addition of chlorobenzene or 2-chloronaphthalene to $[\mathrm{Ni}(\mathrm{COD})(\mathrm{dppf})]$ (1) leads to $[\mathrm{NiCl}(\mathrm{dppf})]$ (2$\mathrm{Cl}),{ }^{15,17}$ while $o$-chlorotoluene produces $[\mathrm{NiCl}(o$-tol $)(\mathrm{dppf})]$ $(3-\mathrm{Cl}){ }^{26}$ On the basis of experiments described here, it is proposed that $[\mathrm{NiCl}(\mathrm{Ar})(\mathrm{dppf})]$ complexes always form initially and that $\mathrm{Ni}^{\mathrm{I}}$ arises from a series of comproportionation and disproportionation events. This is consistent with a recent computational study of this process. ${ }^{18}$

A solution of 1 was exposed to $p-\mathrm{F}_{3} \mathrm{CC}_{6} \mathrm{H}_{4} \mathrm{I}$ at $10{ }^{\circ} \mathrm{C}$ and warmed to $27^{\circ} \mathrm{C}$ in the magnet of the NMR spectrometer, at which point two new species were identified by ${ }^{31} \mathrm{P}\left\{{ }^{1} \mathrm{H}\right\} \mathrm{NMR}$ spectroscopy (Figure 9). One of these is consistent with $\left[\mathrm{NiI}\left(p-\mathrm{F}_{3} \mathrm{CC}_{6} \mathrm{H}_{4}\right)(\mathrm{dppf})\right]$, while the other is as yet unidentified $\left(\delta_{\mathrm{P}} \sim 31 \mathrm{ppm}\right)$; both are consumed as the reaction progresses, to yield no diamagnetic phosphorus-containing species. The expected $\mathrm{Ni}^{\mathrm{II}}$ product of oxidative addition is obtained initially but reacts rapidly in a subsequent process. The unidentified signal is not $\left[\mathrm{Ni}(\mathrm{dppf})_{2}\right]\left(\delta_{\mathrm{p}} 15 \mathrm{ppm}\right)^{78}$ or $\left[\mathrm{NiI}_{2}(\mathrm{dppf})\right]$ (paramagnetic). Attempts to synthesize a model [Ni- 


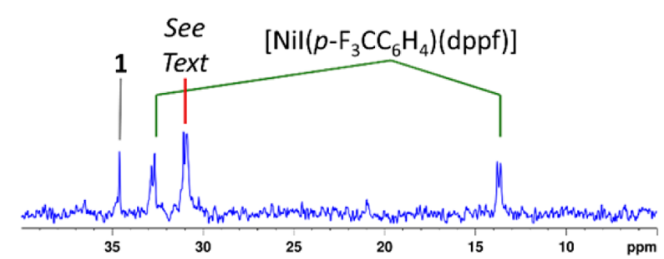

Figure 9. Partial ${ }^{31} \mathrm{P}\left\{{ }^{1} \mathrm{H}\right\}$ NMR spectrum from exposing $[\mathrm{Ni}(\mathrm{COD})$ (dppf)] (1) $\left(0.022 \mathrm{~mol} \mathrm{~L}{ }^{-1}\right)$ in benzene- $d_{6}$ to $p-\mathrm{F}_{3} \mathrm{CC}_{6} \mathrm{H}_{4} \mathrm{I}(0.44 \mathrm{~mol}$ $\left.\mathrm{L}^{-1}\right)$ at $283 \mathrm{~K}$ and warming to $300 \mathrm{~K}$.

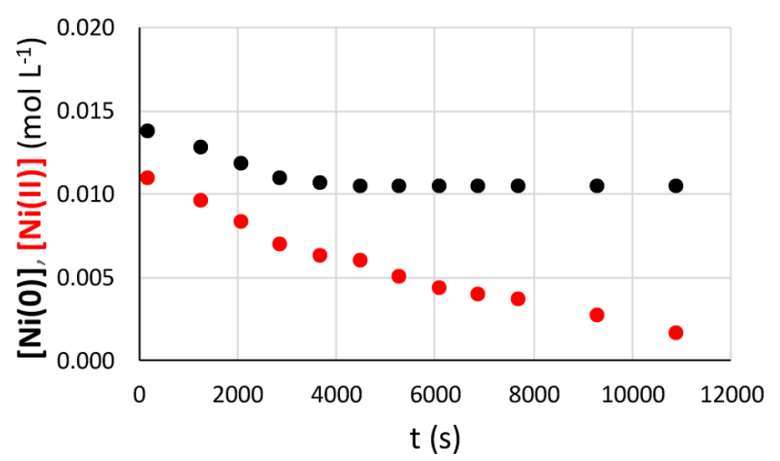

Figure 10. Kinetic profile for the reaction of 1 equiv of $[\mathrm{Ni}(\mathrm{COD})$ (dppf)] (1) (black) and 1 equiv of $\left[\mathrm{NiCl}\left(o-\mathrm{MeC}_{6} \mathrm{H}_{4}\right)(\mathrm{dppf})\right](3-\mathrm{Cl})$ (red) to form $[\mathrm{NiCl}(\mathrm{dppf})](2-\mathrm{Cl})$ in $1 / 1 \mathrm{THF} /$ benzene- $d_{6}$ at $50{ }^{\circ} \mathrm{C}$.

$\left.(\mathrm{Ar})_{2}(\mathrm{dppf})\right]$ complex via the addition of $o-\mathrm{MeC}_{6} \mathrm{H}_{4} \mathrm{MgCl}$ to $\left[\mathrm{NiCl}\left(o-\mathrm{MeC}_{6} \mathrm{H}_{4}\right)(\mathrm{dppf})\right]$ at $-50{ }^{\circ} \mathrm{C}$ in the $\mathrm{NMR}$ spectrometer led only to decomposition, while repeating the experiment (with $o-\mathrm{MeC}_{6} \mathrm{H}_{4} \mathrm{MgCl}$ or $\mathrm{Mes} \mathrm{MgBr}$ ) in the presence of $\mathrm{COD}$ led only to the smooth formation of complex 1 via reductive elimination. The reaction of $\mathbf{1}$ with biphenylene ${ }^{79}$ led to the formation of a new species that was not consistent with the unknown species in Figure $9\left(\delta_{\mathrm{P}} \sim 13 \mathrm{ppm}\right)$. Notably, very few $\left[\mathrm{Ni}(\mathrm{Ar})_{2}(\mathrm{~L})\right]$ complexes have been reported with bidentate ligands (such as $\left.\left[\mathrm{Ni}(\mathrm{Mes})_{2}(\mathrm{bpy})\right]\right) ;^{80,81}$ however, some trans$\left[\mathrm{Ni}(\mathrm{Ar})_{2}(\mathrm{~L})_{2}\right]$ species $^{69,82-84}$ of often limited stability ${ }^{85}$ are known.

$\left[\mathrm{NiCl}\left(o-\mathrm{MeC}_{6} \mathrm{H}_{4}\right)(\mathrm{dppf})\right](3-\mathrm{Cl})$ is relatively stable in solution at room temperature and at slightly elevated temperatures $^{26}$ but decomposes when it is heated in the presence of $1 .^{86}$ The production of biaryl is therefore predominantly via a comproportionation step to form $[\mathrm{NiCl}-$ (dppf)] (2-Cl). An alternative mechanism could be envisaged, in which ligand scrambling ${ }^{87}$ between two molecules of 3-Cl leads to $\left[\mathrm{Ni}\left(o-\mathrm{MeC}_{6} \mathrm{H}_{4}\right)_{2}(\mathrm{dppf})\right]$ and $\left[\mathrm{NiCl}_{2}(\mathrm{dppf})\right]$, which is then followed by reductive elimination to form biaryl and comproportionation to form two molecules of $[\mathrm{NiCl}(\mathrm{dppf})]$; $^{88}$ this process is known to be energetically favorable overall, on the basis of calculated values of $\Delta G_{\mathrm{rxn}}{ }^{19}$ However, kinetic experiments show that such a process is much less competent than the reaction between $\mathbf{3 - C l}$ and $\mathbf{1}$ : the comproportionation reaction between $\mathbf{1}$ and $3-\mathbf{C l}$ was profiled (Figure 10 ); $25 \%$ of complex $\mathbf{1}$ is consumed but all of $3-\mathrm{Cl}$ reacts. When the reaction is repeated in the presence of added COD, no comproportionation occurs. Other studies have reported the comproportionation of $\left[\mathrm{Ni}(\mathrm{dppf})(\mathrm{L})_{n}\right]$ complexes with $[\mathrm{Ni}$ $(\mathrm{Ar}) \mathrm{X}(\mathrm{dppf})]$ but have not reported kinetic data. ${ }^{17,18}$ Our data show that the comproportionation is mediated by $\mathrm{Ni}^{0}$ but does not consume most of the $\mathrm{Ni}^{0}$.

A proposal for the mechanism of the formation of $\mathbf{2}-\mathbf{X}$ from oxidative addition reactions is presented in Scheme 3.
Comproportionation leads to $[\mathrm{NiX}(\mathrm{dppf})](\mathbf{2}-\mathrm{X})$ and a $\mathrm{Ni}^{\mathrm{I}}-$ aryl species (Scheme 3a). ${ }^{18}$ Notably, isolable $\left[\mathrm{Ni}(\mathrm{Ar})(\mathrm{L})_{n}\right]$

Scheme 3. Proposed Mechanism for the Formation of $[\mathrm{NiX}(\mathrm{dppf})](2-\mathrm{X})$ from the Oxidative Addition of Aryl (Pseudo)halides to $[\mathrm{Ni}(\mathrm{COD})(\mathrm{dppf})](1)$
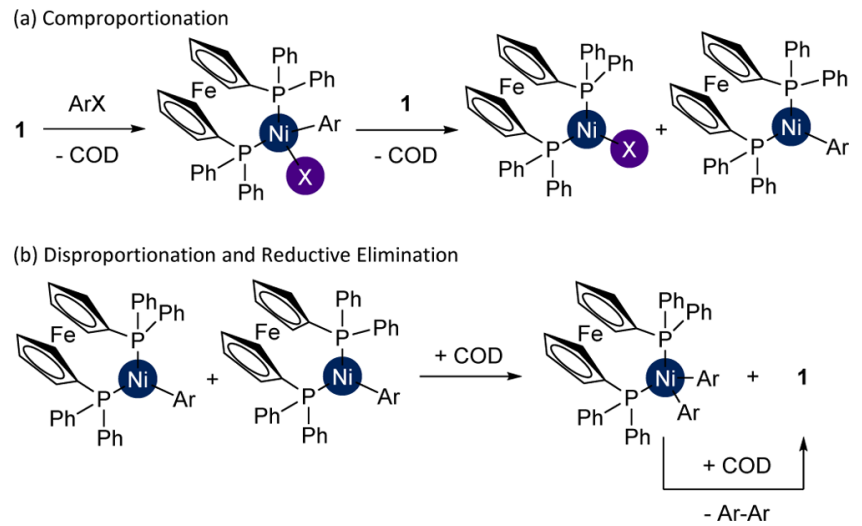

(c) Hydrogen Atom Abstraction

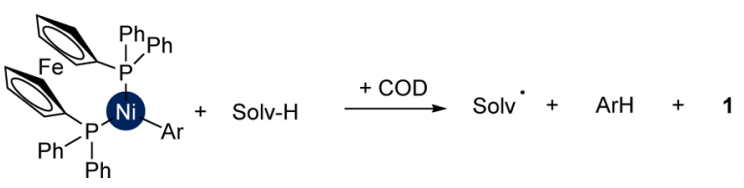

Scheme 4. Prototypical Reactions To Assess the Effect of Electrophile Identity on Reactivity in Catalysis Mediated by $[\mathrm{Ni}(\mathrm{COD})(\mathrm{dppf})](1)$
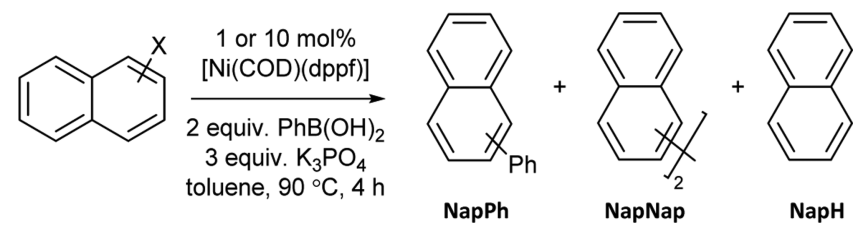

complexes are rather rare. ${ }^{89}$ We propose that disproportionation of the latter leads to a $\mathrm{Ni}^{0}$ complex that is recaptured by COD and a bi(aryl) complex that undergoes reductive elimination (Scheme 3b). Alternatively, hydrogen atom abstraction from the solvent might lead to $\left[\mathrm{Ni}^{0}(\mathrm{dppf})\right]$ and arene (Scheme $3 b)$ ); arene and biaryl byproducts have been observed in various oxidative addition reaction mixtures during this work and in catalytic reactions in the literature. ${ }^{18}$ The following evidence is consistent with this proposal: (i) the presence of $\mathbf{1}$ significantly increases the rate at which $3-\mathrm{Cl}$ is converted to 2-Cl, via comproportionation, (ii) the addition of $o-\mathrm{MeC}_{6} \mathrm{H}_{4} \mathrm{MgCl}$ to $[\mathrm{NiCl}(\mathrm{dppf})]$ in the presence of COD leads to 1 without detectable intermediates, (iii) attempts to form $\left[\mathrm{Ni}(\mathrm{Ar})_{2}(\mathrm{dppf})\right]$ in an analogous manner, using o$\mathrm{MeC}_{6} \mathrm{H}_{4} \mathrm{MgCl}$ or $\mathrm{MesMgBr}$ in the presence of COD, lead to 1 without detectable intermediates, and (iv) the comproportionation reaction is not stoichiometric in complex $1 .{ }^{90}$ Both the disproportionation and hydrogen atom abstraction mechanisms appear to be operative, although the former is favored in reactions of aryl halides without ortho substitutents (vide supra).

The fact that the major pathway relies on 1 requires careful consideration of the kinetics of the oxidative addition reaction. Complex $\mathbf{1}$ is involved in a pseudo-first-order oxidative addition step in which it is consumed (with observed rate constant 
Table 3. Results from Suzuki-Miyaura Reactions with 1And 2-Naphthyl (Pseudo)halides Catalyzed by $[\mathrm{Ni}(\mathrm{COD})(\mathrm{dppf})](1)^{a}$

\begin{tabular}{|c|c|c|c|c|}
\hline substrate & {$[1](\mathrm{mol} \%)$} & $\mathrm{NapPh}$ & NapNap & $\mathrm{NapH}$ \\
\hline $1-\mathrm{Br}$ & 10 & 97 & $<1$ & 3 \\
\hline 1-OTs & 10 & 96 & $<1$ & 3 \\
\hline 1-OTf & 10 & 95 & $<1$ & 2 \\
\hline $1-\mathrm{OCO}_{2} \mathrm{Et}$ & 10 & 64 & 3 & 5 \\
\hline 1-OCONEt ${ }_{2}$ & 10 & 19 & 1 & 9 \\
\hline $1-\mathrm{OSO}_{2} \mathrm{NMe}_{2}$ & 10 & 24 & 2 & 3 \\
\hline 1-OPiv & 10 & 14 & 1 & 8 \\
\hline $1-\mathrm{Br}$ & 1 & 24 & $<1$ & $<1$ \\
\hline 1-OTs & 1 & 32 & $<1$ & 2 \\
\hline 1-OTf & 1 & 34 & $<1$ & 1 \\
\hline $1-\mathrm{OCO}_{2} \mathrm{Et}$ & 1 & 11 & & \\
\hline 1-OCONEt ${ }_{2}$ & 1 & 2 & & \\
\hline $1-\mathrm{Br}$ & 10 & 93 & 6 & 1 \\
\hline 1-OTs & 10 & 94 & 5 & 1 \\
\hline 1-OTf & 10 & 96 & 2 & 2 \\
\hline $1-\mathrm{OCO}_{2} \mathrm{Et}$ & 10 & 40 & 3 & 1 \\
\hline 1-OCONEt ${ }_{2}$ & 10 & 25 & & 1 \\
\hline $1-\mathrm{OSO}_{2} \mathrm{NMe}_{2}$ & 10 & 17 & 5 & 3 \\
\hline 1-OPiv & 10 & 18 & 11 & 4 \\
\hline $1-\mathrm{Br}$ & 1 & 29 & 4 & \\
\hline 1-OTs & 1 & 30 & 2 & $<1$ \\
\hline 1-OTf & 1 & 33 & 2 & \\
\hline $1-\mathrm{OCO}_{2} \mathrm{Et}$ & 1 & 20 & & $<1$ \\
\hline 1-OCONEt ${ }_{2}$ & 1 & 6 & & \\
\hline
\end{tabular}

${ }^{a}$ The balance of the material is unreacted naphthyl (pseudo)halide. Reaction conditions: $10 \mathrm{~mol} \%$ of $[\mathrm{Ni}(\mathrm{COD})(\mathrm{dppf})](\mathbf{1}), 2$ equiv of $\mathrm{PhB}(\mathrm{OH})_{2}, 3$ equiv of $\mathrm{K}_{3} \mathrm{PO}_{4}$, toluene, $90{ }^{\circ} \mathrm{C}$, $4 \mathrm{~h}$. All outcomes were quantified using calibrated GC-FID analysis.

$k_{\mathrm{obs}}^{\mathrm{OA}}$ ) and a second-order process in which it mediates comproportionation and the formation of biaryl (with observed rate constant $k_{\mathrm{obs}}{ }^{\mathrm{Com}}$ ). Therefore, the consumption of $\mathbf{1}$ can be approximated to eq 4 . However (i) the latter process does not consume 1 , (ii) $\left[\mathrm{Ni}^{\mathrm{II}}(\mathrm{Ar}) \mathrm{X}(\mathrm{dppf})\right]$ is always very low for parasubstituted aryl halides because it is not observed by ${ }^{31} \mathrm{P}$ NMR spectroscopy under the reaction conditions, and (iii) this second process is much faster than oxidative addition due to the lack of a buildup of the $\mathrm{Ni}^{\mathrm{II}}$ complex. This explains the good fit of the experimental data for [1] versus time to a pseudo-firstorder process. The observed rate constants obtained are sufficient to quantify and compare the rates at which different aryl (pseudo)halides undergo reaction with $\mathbf{1}^{91}$

$$
\mathrm{d}[\mathbf{1}] / \mathrm{d} t=-k_{\mathrm{obs}}{ }^{\mathrm{OA}}[\mathbf{1}]-k_{\mathrm{obs}}{ }^{\mathrm{Com}}[\mathbf{1}][\mathrm{Ni}(\mathrm{Ar}) \mathrm{X}(\mathrm{dppf})]
$$

Relationship between Oxidative Addition and Catalysis. The rate and selectivity of oxidative addition will have implications for catalysis. Previous studies of $[\mathrm{NiCl}(\mathrm{dppf})]$ suggest that it is an inferior catalyst at best ${ }^{17}$ and completely inactive at worst. $^{15}$ The reactions of 1 - and 2-naphthyl substrates were considered to allow the effects of both electrophile identity and ortho-substitution pattern to be considered. $^{92}$ The model reactions in Scheme 4 were considered; the outcomes were quantified by GC-FID analysis calibrated for each analyte (Table 3 ).

The correlation between oxidative addition rate (see Figure 5) and reaction outcome is neither linear nor perfect, but it shows that any substrate which undergoes oxidative addition more slowly than the aryl carbonate is unlikely to yield favorable results in catalysis under these conditions. In contrast to the measured rates of oxidative addition, the triflate and tosylate substrates achieve very similar results in catalysis; similarly, the carbonate performs much more poorly than the triflate, despite the oxidative addition step occurring at a similar rate. The identity of the electrophile has an effect on catalysis at stages other than oxidative addition. It will affect subsequent steps in the catalytic cycle such as transmetalation: a different $[\mathrm{Ni}(\mathrm{Ar}) \mathrm{X}(\mathrm{dppf})]$ complex is formed which will undergo transmetalation (or be converted to the hydroxide complex) (33 $^{93}$ at a different rate. ${ }^{23}$ The oxidative addition rate is measured under carefully controlled conditions where relatively few factors can be changed; in contrast, the optimization of catalytic reactions requires careful study of the effects of concentration, solvent, catalyst loading, base identity and quantity, coupling partner identity and quantity, and so forth. The poor performance of the more reluctant electrophiles in crosscoupling reactions shows that the oxidative addition rate plays a significant role in determining the feasibility of catalytic reactions. In addition, substrates that lead to $\mathrm{Ni}^{\mathrm{I}}$ products more readily (i.e., 2-naphthyl substrates) show an increased

\section{Scheme 5. Summary of the Outcomes of This Study}

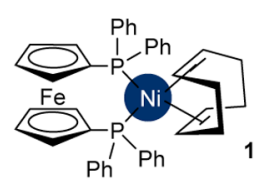

- Fast pre-equilibrium for COD displacement

- Inhibited by added COD

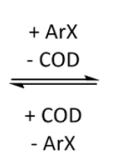

- Oxidative addition rate decreases as: $\mathrm{I}>\mathrm{Br}>\mathrm{Cl}>\mathrm{OTs}>\mathrm{OCO}_{2} \mathrm{Et} \sim \mathrm{OTf}>$

$\mathrm{CONEt}_{2}>\mathrm{OSO}_{2} \mathrm{NMe}_{2}>\mathrm{OPiv}>\mathrm{F} \sim \mathrm{OMe}$

- First order in ArX
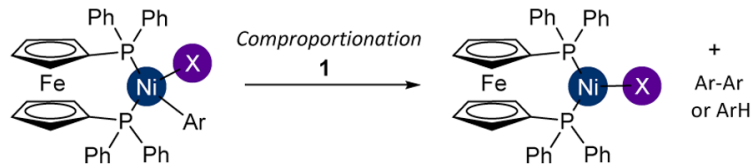

- $\mathrm{Ni}^{\text {Il }}$ stability depends on Ar ortho-substituents

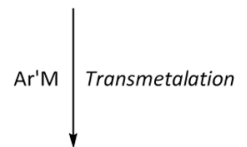

but does not consume 1

- Homocoupling by-product wastes valuable material

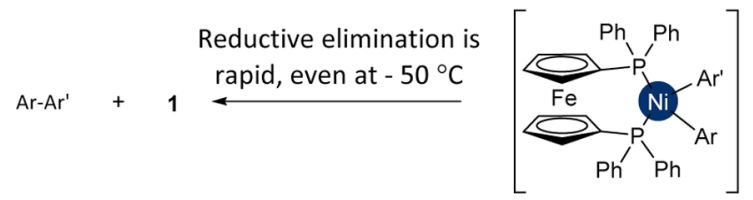


propensity to form deleterious homocoupling side products. The mechanism outlined above may well be the means by which $\mathrm{Ni}^{\mathrm{I}}$ forms in a multitude of other reactions.

\section{CONCLUSIONS}

The outcomes of this study are summarized below and in Scheme 5. These advance our understanding of mechanism and structure/activity relationships in nickel catalysis. Most importantly, we present the most detailed reactivity scale to date for the oxidative addition of aryl electrophiles to a model nickel catalyst. Further studies are underway to map different ligand systems that are relevant to nickel catalysis onto this scale. We have investigated the mechanism of the oxidative addition to $[\mathrm{Ni}(\mathrm{COD})(\mathrm{dppf})]$ (1); COD displacement is necessary to allow the reaction to occur but is not ratedetermining. This is important because many synthetic protocols use catalysts generated in situ from ligands and $\left[\mathrm{Ni}(\mathrm{COD})_{2}\right]$. [NiX(dppf)] arises primarily from comproportionation of $[\mathrm{Ni}(\mathrm{Ar}) \mathrm{X}(\mathrm{dppf})]$ with $[\mathrm{Ni}(\mathrm{COD})(\mathrm{dppf})]$, leading to the formation of biaryl. The propensity of substrates to form $[\mathrm{NiX}(\mathrm{dppf})]$ is a factor of the steric effect of the ortho substituent, and in catalytic reactions, substrates that lead to $\mathrm{Ni}^{\mathrm{I}}$ produce more unwanted homocoupling side products. Further studies are currently underway in our laboratory with the aim of extending and applying this reactivity scale. The raw data underpinning this study (NMR spectroscopy data for characterisation and kinetic studies, EPR spectroscopy data for paramagnetic complexes, GC-FID data from catalysis) is available from http://dx.doi.org/10.15129/85c810eb-cdb3420c-8957-d392ad76ce11. Crystallographic data for $(\mathbf{2}-\mathbf{B r})_{2}$ and $(2-\mathrm{I})_{2}$ can be retrieved from the CCDC (1478811 and 1478812) via www.ccdc.cam.ac.uk/structures/.

\section{ASSOCIATED CONTENT}

\section{S Supporting Information}

The Supporting Information is available free of charge on the ACS Publications website at DOI: 10.1021/acs.organomet.7b00208.

Synthetic procedures and NMR spectra for organometallic and organic compounds, details of kinetic studies, EPR spectra and experimental details, and experimental details for catalytic reactions (PDF) Crystallographic information (CIF)

\section{AUTHOR INFORMATION}

\section{Corresponding Authors}

*E-mail for S.S.: Stephen.Sproules@glasgow.ac.uk. *E-mail for D.J.N.: david.nelson@strath.ac.uk.

\section{ORCID $\odot$}

Alan R. Kennedy: 0000-0003-3652-6015

Stephen Sproules: 0000-0003-3587-0375

David J. Nelson: 0000-0002-9461-5182

\section{Present Address}

${ }^{\S}$ Departamento de Química Inorgánica, Instituto de Śintesis Química y Catálisis Homogénea (ISQCH), Centro de Innovación en Química Avanzada (ORFEO-CINQA), Universidad de Zaragoza-CSIC, 50009 Zaragoza, Spain.

\section{Notes}

The authors declare no competing financial interest.

\section{ACKNOWLEDGMENTS}

This research was generously funded by the Engineering and Physical Sciences Research Council (EP/M027678/1). D.J.N. thanks the University of Strathclyde for a Chancellor's Fellowship. G.L. thanks the EPSRC and the University of Strathclyde for a Vacation Bursary. We thank Dr. John Parkinson for running $\left[{ }^{1} \mathrm{H},{ }^{1} \mathrm{H}\right]$ EXSY experiments, Professor Jonathan Percy for access to laboratory equipment and chemicals, and Professor Robert Mulvey and Dr. Allan Watson for helpful discussions. We are grateful to Craig Irving, Patricia Keating, Alexander Clunie, and Gavin Bain for their assistance with technical and analytical facilities.

\section{ABBREVIATIONS}

dppf, 1,1'-bis(diphenylphosphino)ferrocene; bpy, 2,2'-bipyridine; COD, 1,5-cyclooctadiene

\section{REFERENCES}

(1) Tasker, S. Z.; Standley, E. A.; Jamison, T. F. Nature 2014, 509, 299.

(2) Rosen, B. M.; Quasdorf, K. W.; Wilson, D. A.; Zhang, N.; Resmerita, A.-M.; Garg, N. K.; Percec, V. Chem. Rev. 2011, 111, 1346.

(3) Cornella, J.; Zarate, C.; Martin, R. Chem. Soc. Rev. 2014, 43, 8081.

(4) Yoshikai, N.; Mashima, H.; Nakamura, E. J. Am. Chem. Soc. 2005, 127, 17978

(5) Schaub, T.; Backes, M.; Radius, U. J. Am. Chem. Soc. 2006, 128, 15964.

(6) Shaw, M. H.; Twilton, J.; MacMillan, D. W. C. J. Org. Chem. 2016, 81, 6898.

(7) Tellis, J. C.; Kelly, C. B.; Primer, D. N.; Jouffroy, M.; Patel, N. R.; Molander, G. A. Acc. Chem. Res. 2016, 49, 1429.

(8) Terrett, J. A.; Cuthbertson, J. D.; Shurtleff, V. W.; MacMillan, D. W. C. Nature 2015, 524, 330.

(9) Corcoran, E. B.; Pirnot, M. T.; Lin, S.; Dreher, S. D.; DiRocco, D. A.; Davies, I. W.; Buchwald, S. L.; MacMillan, D. W. C. Science 2016, 353, 279.

(10) Ananikov, V. P. ACS Catal. 2015, 5, 1964.

(11) Durr, A. B.; Yin, G.; Kalvet, I.; Napoly, F.; Schoenebeck, F. Chem. Sci. 2016, 7, 1076.

(12) Cornella, J.; Gómez-Bengoa, E.; Martin, R. J. Am. Chem. Soc. 2013, 135, 1997.

(13) Schley, N. D.; Fu, G. C. J. Am. Chem. Soc. 2014, 136, 16588.

(14) Ge, S.; Green, R. A.; Hartwig, J. F. J. Am. Chem. Soc. 2014, 136, 1617.

(15) Yin, G.; Kalvet, I.; Englert, U.; Schoenebeck, F. J. Am. Chem. Soc. 2015, 137, 4164.

(16) Nicolas, E.; Ohleier, A.; D’Accriscio, F.; Pécharman, A.-F.; Demange, M.; Ribagnac, P.; Ballester, J.; Gosmini, C.; Mézailles, N. Chem. - Eur. J. 2015, 21, 7690.

(17) Guard, L. M.; Mohadjer Beromi, M.; Brudvig, G. W.; Hazari, N.; Vinyard, D. J. Angew. Chem., Int. Ed. 2015, 54, 13352.

(18) Mohadjer Beromi, M.; Nova, A.; Balcells, D.; Brasacchio, A. M.; Brudvig, G. W.; Guard, L. M.; Hazari, N.; Vinyard, D. J. J. Am. Chem. Soc. 2017, 139, 922.

(19) Kalvet, I.; Guo, Q.; Tizzard, G. J.; Schoenebeck, F. ACS Catal. 2017, 7, 2126.

(20) Clark, J. S. K.; Voth, C. N.; Ferguson, M. J.; Stradiotto, M. Organometallics 2017, 36, 679.

(21) Henrion, M.; Ritleng, V.; Chetcuti, M. J. ACS Catal. 2015, 5, 1283.

(22) Ritleng, V.; Henrion, M.; Chetcuti, M. J. ACS Catal. 2016, 6, 890.

(23) Casado, A. L.; Espinet, P. J. Am. Chem. Soc. 1998, 120, 8978.

(24) Leowanawat, P.; Zhang, N.; Percec, V. J. Org. Chem. 2012, 77, 1018.

(25) The very poor solubility of these complexes necessitated the use of saturated solutions to obtain satisfactory spectra. Unfortunately, this 
precludes the use of spin integration to quantify $\mathrm{Ni}^{\mathrm{I}}$ yields by EPR spectroscopy.

(26) Park, N. H.; Teverovskiy, G.; Buchwald, S. L. Org. Lett. 2014, 16, 220.

(27) Standley, E. A.; Smith, S. J.; Müller, P.; Jamison, T. F. Organometallics 2014, 33, 2012.

(28) The limited solubility of $\mathbf{1}$ and the sensitivity of the spectrometer mean that data can be acquired every ca. $6 \mathrm{~min}$ at best. All rate constants reported are obtained from data that give a good fit to first order for the first ca. 3 half-lives.

(29) Tsou, T. T.; Kochi, J. K. J. Am. Chem. Soc. 1979, 101, 6319.

(30) Foa, M.; Cassar, L. J. Chem. Soc., Dalton Trans. 1975, 2572.

(31) Brauer, D. J.; Krueger, C. Inorg. Chem. 1977, 16, 884.

(32) The mechanism might proceed via dissociation of one COD alkene and coordination of the substrate. However, if this were the case, it would also lead to COD exchange via the stepwise dissociation of one alkene, association of another COD molecule, and dissocation of the original COD molecule.

(33) Zenkina, O. V.; Karton, A.; Freeman, D.; Shimon, L. J. W.; Martin, J. M. L.; van der Boom, M. E. Inorg. Chem. 2008, 47, 5114.

(34) Hansch, C.; Leo, A.; Taft, R. W. Chem. Rev. 1991, 91, 165.

(35) $p$-Chlorobenzamide and $N$-( $p$-chlorophenyl)succinamide are insufficiently soluble for study, while $p$-chloroacetophenone, $p$ chlorobenzophenone, and diethyl $p$-chlorobenzamide reacted extraordinarily quickly, with half-lives of much less than $10 \mathrm{~min}$. The last three substrates are currently being examined in more detail in our laboratory.

(36) Portnoy, M.; Milstein, D. Organometallics 1993, 12, 1665.

(37) Ahlquist, M.; Norrby, P.-O. Organometallics 2007, 26, 550.

(38) Stille, J. K.; Lau, K. S. Y. Acc. Chem. Res. 1977, 10, 434.

(39) Amatore, C.; Jutand, A.; Suarez, A. J. Am. Chem. Soc. 1993, 115, 9531.

(40) Jutand, A.; Hii, K. K.; Thornton-Pett, M.; Brown, J. M. Organometallics 1999, 18, 5367.

(41) Roy, A. H.; Hartwig, J. F. Organometallics 2004, 23, 194.

(42) Hegedus, L. S.; Thompson, D. H. P. J. Am. Chem. Soc. 1985, $107,5663$.

(43) Amatore, C.; Pfluger, F. Organometallics 1990, 9, 2276.

(44) Li, B.-J.; Yu, D.-G.; Sun, C.-L.; Shi, Z.-J. Chem. - Eur. J. 2011, 17, 1728

(45) Tang, Z.-Y.; Hu, Q.-S. J. Am. Chem. Soc. 2004, 126, 3058.

(46) Leowanawat, P.; Zhang, N.; Resmerita, A.-M.; Rosen, B. M.; Percec, V. J. Org. Chem. 2011, 76, 9946.

(47) Antoft-Finch, A.; Blackburn, T.; Snieckus, V. J. Am. Chem. Soc. 2009, 131, 17750.

(48) Tobisu, M.; Shimasaki, T.; Chatani, N. Angew. Chem., Int. Ed. 2008, 47, 4866.

(49) Álvarez-Bercedo, P.; Martin, R. J. Am. Chem. Soc. 2010, 132, 17352.

(50) Tobisu, M.; Xu, T.; Shimasaki, T.; Chatani, N. J. Am. Chem. Soc. 2011, 133, 19505 .

(51) Quasdorf, K. W.; Tian, X.; Garg, N. K. J. Am. Chem. Soc. 2008, 130,14422

(52) Hie, L.; Fine Nathel, N. F.; Hong, X.; Yang, Y.-F.; Houk, K. N.; Garg, N. K. Angew. Chem., Int. Ed. 2016, 55, 2810.

(53) Zim, D.; Lando, V. R.; Dupont, J.; Monteiro, A. L. Org. Lett. 2001, 3, 3049.

(54) Gao, H.; Li, Y.; Zhou, Y.-G.; Han, F.-S.; Lin, Y.-J. Adv. Synth. Catal. 2011, 353, 309.

(55) Quasdorf, K. W.; Antoft-Finch, A.; Liu, P.; Silberstein, A. L.; Komaromi, A.; Blackburn, T.; Ramgren, S. D.; Houk, K. N.; Snieckus, V.; Garg, N. K. J. Am. Chem. Soc. 2011, 133, 6352.

(56) Li, Z.; Zhang, S.-L.; Fu, Y.; Guo, Q.-X.; Liu, L. J. Am. Chem. Soc. 2009, 131, 8815 .

(57) $p-\mathrm{F}_{3} \mathrm{CC}_{6} \mathrm{H}_{4} \mathrm{Cl}$ undergoes reaction approximately $30 \%$ more slowly in toluene- $d_{8}$ than in benzene- $d_{6}$ at $323 \mathrm{~K}$. However, $p$ $\mathrm{F}_{3} \mathrm{CC}_{6} \mathrm{H}_{4} \mathrm{Br}$ and $p-\mathrm{F}_{3} \mathrm{CC}_{6} \mathrm{H}_{4} \mathrm{OTs}$ are studied under two reaction conditions each, in order to allow relative rates to be quantified in the reactivity scale.
(58) Complex $\mathbf{1}$ is stable in toluene- $d_{8}$ under these conditions, with only ca. $1 \%$ decomposition observed after $48 \mathrm{~h}$ in the absence of aryl halide.

(59) Jutand, A.; Mosleh, A. Organometallics 1995, 14, 1810.

(60) Alcazar-Roman, L. M.; Hartwig, J. F. Organometallics 2002, 21, 491.

(61) Hills, I. D.; Netherton, M. R.; Fu, G. C. Angew. Chem., Int. Ed. 2003, 42, 5749 .

(62) Langer, J.; Fischer, R.; Görls, H.; Theyssen, N.; Walther, D. Z. Anorg. Allg. Chem. 2007, 633, 557.

(63) Page, M. J.; Lu, W. Y.; Poulten, R. C.; Carter, E.; Algarra, A. G.; Kariuki, B. M.; Macgregor, S. A.; Mahon, M. F.; Cavell, K. J.; Murphy, D. M.; Whittlesey, M. K. Chem. - Eur. J. 2013, 19, 2158.

(64) Beck, R.; Shoshani, M.; Krasinkiewicz, J.; Hatnean, J. A.; Johnson, S. A. Dalton Trans. 2013, 42, 1461.

(65) Mindiola, D. J.; Hillhouse, G. L. J. Am. Chem. Soc. 2001, 123, 4623.

(66) Holland, P. L.; Cundari, T. R.; Perez, L. L.; Eckert, N. A.; Lachicotte, R. J. J. Am. Chem. Soc. 2002, 124, 14416.

(67) Bai, G.; Wei, P.; Stephan, D. W. Organometallics 2005, 24, 5901.

(68) Mabbs, F. E.; Collison, D. Electron Paramagnetic Resonance of $d$ Transition Metal Complexes; Elsevier: Amsterdam, 1992.

(69) Wada, M.; Kusabe, K.; Oguro, K. Inorg. Chem. 1977, 16, 446.

(70) Fahey, D. R.; Baldwin, B. A. Inorg. Chim. Acta 1979, 36, 269.

(71) Chatt, J.; Shaw, B. L. J. Chem. Soc. 1960, 1718.

(72) Hidai, M.; Kashiwagi, T.; Ikeuchi, T.; Uchida, Y. J. Organomet. Chem. 1971, 30, 279.

(73) Uchino, M.; Asagi, K.; Yamamoto, A.; Ikeda, S. J. Organomet. Chem. 1975, 84, 93.

(74) Semmelhack, M. F.; Helquist, P.; Jones, L. D.; Keller, L.; Mendelson, L.; Ryono, L. S.; Gorzynski Smith, J.; Stauffer, R. D. J. Am. Chem. Soc. 1981, 103, 6460.

(75) Biswas, S.; Weix, D. J. J. Am. Chem. Soc. 2013, 135, 16192.

(76) Shields, B. J.; Doyle, A. G. J. Am. Chem. Soc. 2016, 138, 12719.

(77) Dubinina, G. G.; Brennessel, W. W.; Miller, J. L.; Vicic, D. A. Organometallics 2008, 27, 3933.

(78) Pilloni, G.; Toffoletti, A.; Bandoli, G.; Longato, B. Inorg. Chem. 2006, 45, 10321.

(79) Eisch, J. J.; Piotrowski, A. M.; Han, K. I.; Kruger, C.; Tsay, Y. H. Organometallics 1985, 4, 224.

(80) Klein, A. Z. Anorg. Allg. Chem. 2001, 627, 645.

(81) Seidel, W. Z. Chem. 1985, 25, 411.

(82) Arcas, A.; Royo, P. Inorg. Chim. Acta 1978, 30, 205.

(83) Arcas, A.; Royo, P. Inorg. Chim. Acta 1978, 31, 97.

(84) Casares, J. A.; Espinet, P.; Martín-Alvarez, J. M.; MartínezIlarduya, J. M.; Salas, G. Eur. J. Inorg. Chem. 2005, 2005, 3825.

(85) Parshall, G. W. J. Am. Chem. Soc. 1974, 96, 2360.

(86) On heating in benzene- $d_{6}$ at $323 \mathrm{~K}$ in the presence of an internal standard, 9\% decomposition was observed after $24 \mathrm{~h}$. In a $2 / 1$ benzene- $d_{6} /$ THF mixture, less than $1 \%$ decomposition was observed after $24 \mathrm{~h}$ at $323 \mathrm{~K}$.

(87) Jones, G. D.; Anderson, T. J.; Chang, N.; Brandon, R. J.; Ong, G. L.; Vicic, D. A. Organometallics 2004, 23, 3071.

(88) Yamamoto, T.; Wakabayashi, S.; Osakada, K. J. Organomet. Chem. 1992, 428, 223.

(89) Hatnean, J. A.; Shoshani, M.; Johnson, S. A. Inorg. Chim. Acta 2014, 422, 86.

(90) We propose that the initial decrease in [1] is due to the low concentration of COD present until the reaction has progressed. If $\mathrm{Ni}(\mathrm{dppf})$ is not captured by COD, it decomposes, as shown by reactions of $[\mathrm{Ni}(\mathrm{Ar}) \mathrm{X}(\mathrm{dppf})]$ with $\mathrm{ArMgX}$ in the absence of COD. However, adding COD inhibits the reaction, because comproportionation relies on a coordinatively unsaturated $[\mathrm{Ni}(\mathrm{dppf})]$ species. In oxidative addition reactions, $[\mathrm{Ni}(\mathrm{dppf})]$ formed in this way can react directly with the aryl halide present.

(91) When reactions are carried out with 5 or 10 equiv of aryl halide, a much poorer fit to a psuedo-first-order kinetic regime is observed. This is possibly because as $[\mathrm{ArX}]$ decreases the equilibrium between $\mathbf{1}$ plus $\operatorname{ArX}$ and $[\mathrm{Ni}(\operatorname{ArX})(\mathrm{dppf})]$ plus COD shifts towards the left. 
(92) A series of $p$-trifluoromethylphenyl (pseudo)halide substrates was considered but (i) trifluorotoluene has a boiling point similar to that of the toluene solvent, which would complicate GC-FID analysis and (ii) and $o$-methyl-p-trifluoromethylphenol is not readily available. In contrast, the higher molecular weights of the naphthalene substrates, products, and byproducts makes GC-FID analysis straightforward, and both isomers of naphthol are readily available.

(93) Christian, A. H.; Müller, P.; Monfette, S. Organometallics 2014, 33, 2134. 